May 1999 • NREL/CP-550-26649

\title{
The Potential for Low-Cost Concentrating Solar Power Systems
}

\section{Preprint prepared for IECEC}

Henry W. Price

National Renewable Energy Laboratory

Stephen Carpenter

Enermodal Engineering Limited

To Be Presented at the Intersociety Energy Conversion Engineering Conference

Vancouver, British Columbia, Canada

August 1-5, 1999

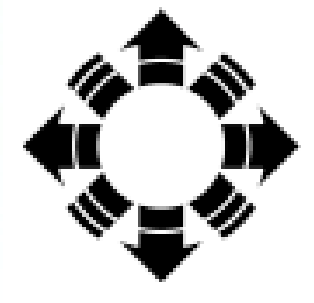

\section{NPEI}

National Renewable Energy Laboratory

1617 Cole Boulevard

Golden, Colorado 80401-3393

NREL is a U.S. Department of Energy Laboratory

Operated by Midwest Research Institute $\bullet$ Battelle $\bullet$ Bechtel

Contract No. DE-AC36-98-G010337 


\section{NOTICE}

This report was prepared as an account of work sponsored by an agency of the United States government. Neither the United States government nor any agency thereof, nor any of their employees, makes any warranty, express or implied, or assumes any legal liability or responsibility for the accuracy, completeness, or usefulness of any information, apparatus, product, or process disclosed, or represents that its use would not infringe privately owned rights. Reference herein to any specific commercial product, process, or service by trade name, trademark, manufacturer, or otherwise does not necessarily constitute or imply its endorsement, recommendation, or favoring by the United States government or any agency thereof. The views and opinions of authors expressed herein do not necessarily state or reflect those of the United States government or any agency thereof.

Available to DOE and DOE contractors from:

Office of Scientific and Technical Information (OSTI)

P.O. Box 62

Oak Ridge, TN 37831

Prices available by calling 423-576-8401

Available to the public from:

National Technical Information Service (NTIS)

U.S. Department of Commerce

5285 Port Royal Road

Springfield, VA 22161

$703-605-6000$ or $800-553-6847$

or

DOE Information Bridge

http://www.doe.gov/bridge/home.html

Printed on paper containing at least $50 \%$ wastepaper, including $20 \%$ postconsumer waste 


\title{
The Potential for Low-Cost Electricity from Concentrating Solar Power Systems
}

\author{
Henry Price \\ National Renewable Energy Laboratory
}

Stephen Carpenter

Enermodal Engineering Limited

\begin{abstract}
Concern over the possibility of global climate change as a result of anthropogenic greenhouse gas buildup in the atmosphere is resulting in increased interest in renewable energy technologies. The World Bank recently sponsored a study to determine whether solar thermal power plants can achieve cost parity with conventional power plants. The paper reviews the conclusions of that study.
\end{abstract}

\section{GLOBAL CLIMATE CHANGE}

There is growing concern over the possibility of global climate change resulting from increased anthropogenic greenhouse gas buildup in the atmosphere. Although there seems to be growing evidence of a global warming trend, the causal relationship to atmospheric greenhouse gases has not been substantiated at present. Current trends show the potential for a doubling of atmospheric greenhouse gases in the next 30 years [EIA, 1999]. This is largely due to economic growth in developing countries. However, should the link between climate change and atmospheric greenhouse gases prove to be correct, the potential for catastrophic environmental impacts in the future is significant. From a risk assessment standpoint it is clear that we need to be making significant efforts today to reduce the potential impact of greenhouse gas emissions in the future.

The United Nations Framework Convention on Climate Change (UNFCCC) seeks to stabilize atmospheric greenhouse gas concentrations at levels that would prevent dangerous anthropogenic interference with global climate. This can be achieved only through dramatically increased utilization of the so-called backstop technologies, such as renewable energy technologies with low emissions of greenhouse gases. The Global Environment Facility (GEF) is an organization set up to deal with global environmental issues including climate change [GEF, 1999a]. The GEF provides grants and funding to developing countries for projects and programs that protect the global environment and promote sustainable economic growth. The GEF is funded primarily by developed nations and is managed by three implementing agencies: the UN Development Programme (UNDP), the UN Environment Programme (UNEP) and the World Bank. The GEF is the primary implementing agency of the UNFCCC.

The GEF has developed a number of operational programs to help increase utilization of these backstop technologies. These programs focus on:

- removing barriers to energy efficiency and energy conservation;

- $\quad$ promoting adoption of renewable energy by removing barriers and reducing implementation costs; and

- reducing the long-term costs of low greenhouse gasemitting energy technologies [GEF, 1996a].

The GEF operational programs utilize a concept known as incremental cost [GEF, 1996b] to define their investment in environmental projects. The incremental cost is the difference between the least-cost conventional alternative that a developing country is likely to use and the preferred environmental option that is preferred for the global environment. The GEF's role is to pay the incremental cost of the environmentally preferred option. The objective of this approach is to promote the deployment of renewable energy technologies so that through learning and economies of scale their levelized energy costs will decline to commercially competitive levels in the future.

The GEF has identified parabolic trough technology as one of the renewable energy technologies it supports in its operational programs. Based on the commercial success of the Solar Electric Generating Systems (SEGS), parabolic trough technology is considered the most proven concentrating solar power technology; still, it is not currently cost effective in most power markets. Thus parabolic trough technology fits into the third area of reducing the long-term cost of low greenhouse gasemitting energy technologies. 


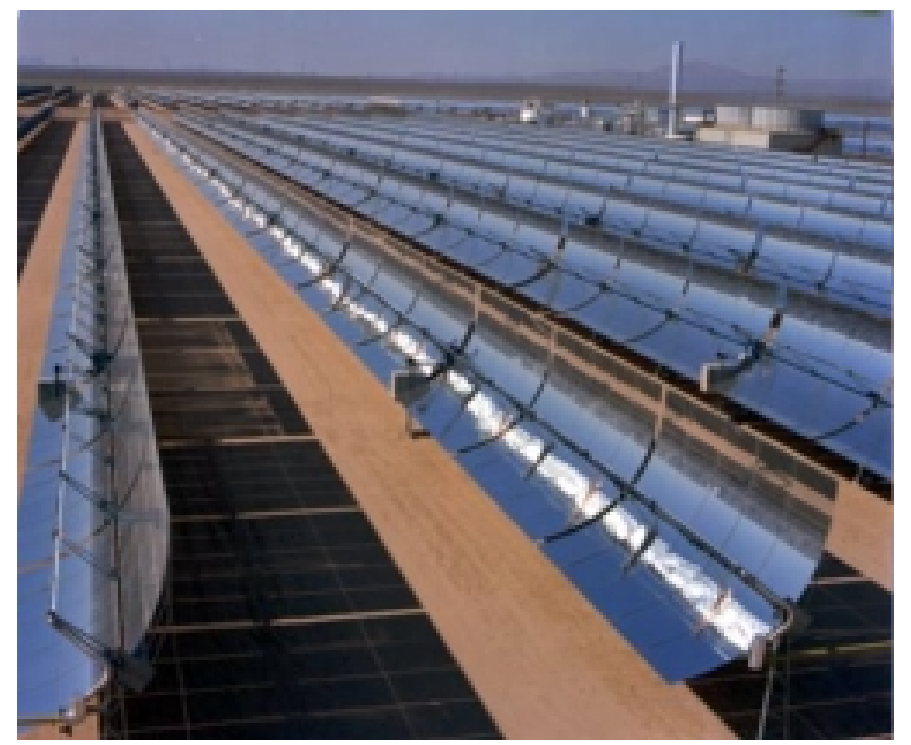

\section{Figure 1 SEGS V Parabolic Trough Solar Thermal Power Plant [KJC Operating Company]}

\section{COMMERCIAL PARABOLIC TROUGH EXPERIENCE}

The parabolic trough solar thermal power plants utilize large fields of parabolic trough solar collectors to supply thermal energy to produce steam to drive a Rankine steam turbine/generator cycle. The parabolic trough collectors have silvered, low-iron glass reflectors that focus direct solar radiation on an efficient evacuated receiver located at the focus of the parabola. Each collector has the capability to track the sun independently from the remainder of the collectors in the solar field. Figure 1 is a picture of an operating parabolic trough solar thermal power plant.

The SEGS parabolic trough plants represent the only large-scale commercial deployment of solar thermal power plant technologies to date. Between 1984 and 1990, Luz International Limited developed, built, and sold nine parabolic trough solar power plants in the California Mojave Desert. These plants, called Solar Electric Generating Stations and referred to as SEGS I-IX, range in size from $14 \mathrm{MWe}$ to $80 \mathrm{MWe}$ and make up a total of $354 \mathrm{MWe}$ of installed generating capacity. Each of these plants was developed as an independent power producer (IPP) project, financed with non-recourse debt, and sold to investor groups. In total, over $\$ 1.2$ billion was raised to finance these projects. The projects were initially driven by the availability of state and federal investment tax credits. Later, special power purchase contracts available in California played a key role. The SEGS projects are qualifying facilities (QFs) as defined by the 1978 Federal Public Utility Regulatory Policies Act (PURPA), which enabled the creation of small non-utility renewable and co-generation power plants. PURPA required local utilities to purchase power from QFs. In 1991, Luz declared bankruptcy while in the process of building its tenth plant as a result of delays in the extension of the California solar property tax exemption and the inability to obtain construction financing. Although many factors contributed to the eventual failure of Luz, the primary cause was decreasing energy prices coinciding with the phasing out of state and federal investment tax credits [Lotker, 1991]. However, Luz achieved significant reductions in the cost of power from parabolic trough solar power plants, from a reported $24 \phi / \mathrm{kWh}$ at SEGS I to about $8 \phi / \mathrm{kWh}$ at SEGS IX.

It is important to note that all of the nine SEGS plants completed continue to operate today. SEGS I, the first plant, is currently in its 15th year of operation. In total, the plants have accumulated more than 100 plant-years of operation. From an operational perspective, the SEGS plants have been very successful. The plants have demonstrated the industrial nature of the Luz parabolic trough collector technology and the ability to dispatch and achieve high on-peak availability for Southern California Edison (SCE), the local power utility. During the ten-year period from 1988 to 1997, the five 30-MWe SEGS plants located at Kramer Junction in California averaged 105\% of rated capacity during the four-month summer on-peak period between 12 noon and 6 p.m. on weekdays [Cable, 1998].

The SEGS plants are hybrid fossil/solar plants, so when insufficient sunlight is available, the turbine can be operated up to full load with fossil (natural gas) energy. On an annual basis $75 \%$ or more of the energy to the plant comes from solar energy, with natural gas providing the balance. The fossil backup capability allows the SEGS plants to be fully dispatchable.

\section{COST REDUCTION STUDY}

In April 1996, the GEF approved an incremental cost grant of $\$ 49$ million for a parabolic trough power project in India [GEF, 1999b]. Since then the GEF has received three additional $\$ 50$ million grant requests for concentrating solar power plants in Morocco, Egypt, and Mexico. Given that the four proposed projects represent a significant financial commitment, the GEF wanted to make sure that the proposed projects would be a significant step in support of the GEF's programmatic objectives. To this end, the World Bank initiated a study [Enermodal, 1999] primarily to assess the cost reduction potential for concentrating solar power technologies. Enermodal Engineering Ltd. and Marbek Resource Consultants Ltd. of Ontario, Canada, were hired to perform a due diligence assessment on solar thermal power plant (STPP) technologies. Given the limited experience of the engineering consultants with STPP technologies, an agreement was reached for SunLab to provide technical support and cost and performance modeling of various STPP technologies. The purpose of the study was to:

${ }^{\mathrm{i}}$ SunLab is a collaboration between Sandia National Laboratories in Albuquerque, NM, and the National Renewable Energy Laboratory in Golden, CO, in support of the U.S. Department of Energy's Office of Power Technology Concentrating Solar Power Program. 
Table 1 Differences Between Private-Sector and Public-Sector Analysis [Enermodal, 1999]

\begin{tabular}{|c|c|c|}
\hline Comparison Item & Private-Sector & Public-Sector \\
\hline Viewpoint & Investor & Overall Society \\
\hline Energy Prices (Benefits) & Prevailing & $\begin{array}{l}\text { Social values reflect willingness to } \\
\text { pay; alternative uses }\end{array}$ \\
\hline Costs & Private, prevailing & $\begin{array}{l}\text { Social values reflect unrealized } \\
\text { opportunities }\end{array}$ \\
\hline External Effects & Ignored & Analyzed as much as possible \\
\hline Taxes & Considered & Ignored \\
\hline Social Infrastructure (e.g., roads) & Ignored & Considered \\
\hline Discount Rate & $\begin{array}{l}\text { Reflects cost of borrowing, desired } \\
\text { returns (often }>10 \%-15 \% \text { ) }\end{array}$ & $\begin{array}{l}\text { Reflects social preferences and } \\
\text { other factors (often } 8 \%-10 \% \text { ) }\end{array}$ \\
\hline Decision Criteria & Payback or IRR above a given rate & $\begin{array}{c}\text { Positive NPV at the Social Discount } \\
\text { Rate }\end{array}$ \\
\hline Time Frame & Short term & Life Cycle \\
\hline
\end{tabular}

- assess the current and future cost competitiveness of STPPs with conventional power systems;

- determine the market potential for STPPs with particular emphasis on developing countries; and

- identify an overall strategy for promoting accelerated development of STPPs, including recommended roles for the key players (in particular the GEF).

STPP Market Potential: Concentrating solar collectors can only focus the sun's direct radiation and cannot concentrate diffuse sky radiation. As a result STPPs will only perform well in very sunny locations, specifically the arid and semi-arid regions of the world. Although the tropics have high solar radiation, the high diffuse solar radiation and long rainy seasons make these regions less desirable for STTP. The best regions for STPP are Southern Africa, Mediterranean countries (including North Africa, the Middle East, and Southern Europe), India, parts of South America, the Southwestern United States and Northern Mexico, and Australia. The operating characteristics of STPPs are relatively well matched with the intermediate and peak electricity load requirements in these regions.

It is important for new power generation technologies to be able to operate during the peak power demand of utilities. In many developing countries the peak demand for power comes after sunset for residential cooking, lighting, and television. In arid regions, an afternoon peak is usually present as well. As countries become more developed, the afternoon peak usually increases in size relative to the evening peak. This is a result of increasing air conditioning and commercial power loads. Solar thermal power plant technologies can incorporate thermal storage that allows daytime thermal collection to be shifted to nighttime electric generation. In general the solar electric output from an STPP appears to roughly match the intermediate-load grid power requirements in arid developing countries.

Developing countries are currently installing about 75,000 MW of new capacity per year. Studies have shown the technical market potential for STPP to be more than $600,000 \mathrm{MW}$ over the next 20 years [Pilkington, 1996]. However, due to the high cost of STPP due to its capitalintensive nature, only a small portion of this potential is likely to be exploited. Near-term developments are likely to be in areas with high fuel costs or restricted access to fuel. Assuming a penetration rate of only $7.5 \%$, the market for STPP is still very large and could reach an annual installation rate of $2000 \mathrm{MW}$.

Economic Analysis: The analysis employed in this study is a public-sector economic analysis; this means that the perspective is that of society as a whole. This is in contrast to a private-sector financial analysis in which the perspective is that of a private investor, such as that used by independent power project developers. This is an important distinction. The basis for conducting privatesector analysis includes market prices, taxes, depreciation, private cost of capital, and applicable incentives, etc. In other words, the private-sector financial analysis attempts to determine the actual costs and revenues that will be realized by the investor. Table 1 illustrates a number of the areas in which public-sector economic analysis differs from the private-sector financial analysis. 
One important reason for employing a public-sector economic approach to the assessment of solar energy options is that price does not always reflect all of the considerations relevant to decision makers. Within the context of this study, one particularly important example is the treatment of external effects, such as greenhouse gas emissions created by each of the electricity generating options. In a private-sector analysis, these emissions are ignored; however, consideration of greenhouse gas emissions is an important driver in the current study. Similarly, it is important to recognize that the conventional technologies and fuels (that provide the "parity target" for the solar technologies) have themselves been affected by subsidies or incentives over many years. In many countries, activities such as petroleum exploration, drilling, and pipeline development have received substantial public development support that necessarily influences their current price.

The study utilized a calculation of levelized energy cost (LEC) to compare competing energy options. The LEC is calculated by taking the levelized annual cash flow (the sum of annual fuel cost, annual operation and maintenance costs, and the product of the fixed charge rate and the capital cost) and dividing it by the annual energy production. By calculating the LEC with constant dollars the effect of inflation can be accounted for.

One of the difficulties in comparing the LEC of STPP options is that the solar output is not always the same. Plants with a low solar contribution (e.g., ISCCS) will have a total plant LEC close to that of conventional (combined cycle) plants giving the impression of being very close to cost-effective status. Furthermore, comparing LEC values of whole plants does not indicate how much the solar cost/performance must improve for the system to be cost effective. To avoid this problem, this report compares LECs of the solar only component. The methodology used is similar to that proposed by Kolb [1998] to determine the solar LEC. The first step is to identify the "baseline," that is, the power plant that will be built if the solar option is not pursued. This plant may or may not be the same size as the solar plant. The initial cost, annual costs, and LEC, are then estimated for this plant. The second step is to determine the LEC for the complete STPP and the non-solar competition. The final step is to back out the LEC for the solar portion of the STPP using the formula given below. The assumption is that the value of the power produced by the STPP when operating on fossil fuel is equal to that of the non-solar competitor.

$L E C_{S O L A R}=\frac{\left[L E C_{S T P P}-(1-F S) \cdot L E C_{C O N}\right]}{F S}$

Where:

$\angle E C_{\text {SOLAR }}$ is the LEC of the solar only component

$\angle E C_{\text {STPP }}$ is the LEC of the STPP (solar and backup components) $\angle E C_{C O N}$ is the LEC of the conventional plant that would have been built in placeof the STPP

FS

is the fraction of the STPP annual capacity factor powered by solar energy.

Conventional Power Technology: In general solar thermal power plant technologies must compete with the conventional power technology that would be built in their place. The report evaluates a number of conventional power technologies: a 400-MW coal-fired Rankine plant, a 300-MW gas or oil Rankine cycle, a 376-MW combined cycle natural gas plant and a 160-MW combustion turbine plant. These plants are typical of plants built in developing countries. The first three plants are typically used to meet intermediate electricity loads (capacity factor $=50 \%$ ), whereas the combustion turbine is typically used to meet peak loads (capacity factor $<25 \%$ ). The cost and performance values were taken from the Annual Energy Outlook 1999 and Gas Turbine World 1997.

There is some indication that the cost of conventional plants is lower in developing countries than in the United States. A contract was recently awarded to construct a 650-MW gas-fired Rankine cycle plant in Egypt. The cost of this system is significantly below the cost given in the Annual Energy Outlook 1999. The lower cost is attributed to a combination of larger capacity and the low labor costs in Egypt. Similarly, a study found a 15\% capital cost saving for a refinery built in India. For consistency, 15\% lower capital and O\&M costs are assumed for both conventional plants and STPPs in developing countries.

The price for coal and natural gas is location dependent. In Egypt, the price for natural gas is $\$ 1 / G J$ whereas in Morocco the price is over $\$ 3 / \mathrm{GJ}$. In this study a median value of $\$ 2.37 / \mathrm{GJ}$ ( $\$ 2.50$ per MMBtu) is used, equal to the World Bank value for Europe. The price for coal using the same reference is $\$ 33$ per metric ton $(\$ 1.14 / \mathrm{GJ})$. All fuel costs are based on the higher heating value.

STPP Technology: The report focused on large-scale grid connected technologies. Parabolic trough technologies were identified as the most commercially ready and available technology based on the experience of the SEGS projects. As a result, the report focused primarily on cost-reduction opportunities for parabolic trough solar power plants. A number of other less developed STPP concepts were also considered in the early phase of the study. The study used molten-salt power towers as a proxy for advanced STPP concepts that might be preferred in the future.

Although no new parabolic trough power plants have been built in the last 10 years, there has been a significant increase in interest as the potential for GEF incremental cost subsidies and special solar tariffs, such as in Spain, becomes a reality. In addition, the technology has continued to improve as a result of the ongoing operating experience at the existing SEGS plants, and the O\&M Cost Reduction Program being carried out at the SEGS III-VII plants by KJC Operating 
Table 2 Parabolic Trough Solar Thermal Power Plant Characteristics [Enermodal, 1999]

\begin{tabular}{|l|c|c|c|c|c|c|}
\hline & \multicolumn{3}{|c|}{$\begin{array}{c}\text { Near-Term } \\
\text { (Next Plant Built) }\end{array}$} & $\begin{array}{c}\text { Mid-Term } \\
(\sim 5 \text { Years) }\end{array}$ & \multicolumn{2}{c|}{$\begin{array}{c}\text { Long-Term } \\
\text { ( 10 Years) }\end{array}$} \\
\hline Power Cycle & Rankine & Rankine & ISCCS & Rankine & Rankine & Rankine \\
Solar Field (000 $\mathbf{~ m}^{\mathbf{2}}$ ) & 193 & 1210 & 183 & 1151 & 1046 & 1939 \\
Storage (hours) & 0 & 0 & 0 & 0 & 0 & 10 \\
Solar Capacity (MW) & 30 & 200 & 30 & 200 & 200 & 200 \\
Total Capacity (MW) & 30 & 200 & 130 & 200 & 200 & 200 \\
Solar Capacity Factor & $25 \%$ & $25 \%$ & $25 \%$ & $25 \%$ & $25 \%$ & $50 \%$ \\
Annual Solar Efficiency & $12.5 \%$ & $13.3 \%$ & $13.7 \%$ & $14.0 \%$ & $16.2 \%$ & $16.6 \%$ \\
Capital Cost (\$/kW) & & & & & & \\
$\quad$ U.S. Plant & 3500 & 2400 & 3100 & 2100 & 1800 & 2500 \\
International & 3000 & 2000 & 2600 & 1750 & 1600 & 2100 \\
O\&M Cost (\$/kWh) & 0.023 & 0.011 & 0.011 & 0.009 & 0.007 & 0.005 \\
\hline Solar LEC (\$/kWh) & $\mathbf{0 . 1 6 6}$ & $\mathbf{0 . 1 0 1}$ & $\mathbf{0 . 1 4 8}$ & $\mathbf{0 . 0 8 0}$ & $\mathbf{0 . 0 6 0}$ & $\mathbf{0 . 0 6 1}$ \\
\hline
\end{tabular}

Company. The direct steam test loop and EuroTrough advanced collector development being undertaken by European industry and laboratories will also help advance the state of the technology. In addition, recent feasibility and project-development studies are resulting in an improved understanding of the potential cost and performance of future plants. The recent parabolic trough technology roadmap (Price, 1999) developed jointly by industry and SunLab also helps to identify the areas that need greater attention in the future. As a result of all these factors, it is believed that the cost of a new parabolic trough plant will be lower than those of any of the SEGS projects.

In this study a number of different plant sizes and configurations were considered including: conventional Rankine cycle plants, much like the existing SEGS plants, and new concepts that integrate a parabolic trough solar plant with a modern combined-cycle plant (Integrated Solar Combined Cycle System or ISCCS). Current and future estimates of capital and O\&M costs, and performance, were based on data from the existing SEGS plants. The trough technology capital cost assumptions were provided by the Pilkington cost model used for the parabolic trough roadmap and are based on the Luz SEGS $X$ cost assumptions. Performance and O\&M cost estimates were extrapolated from actual annual KJC Operating Company data. Table 2 presents the design, cost and performance characteristics of the current and future parabolic trough plants in this study.

From Table 2 we can see that size has a relatively important impact on solar power cost. As a result, this study assumes mid-term and long-term technologies will be the larger size. Integration with combined-cycle power systems also helps reduce solar cost. The analysis methodology used here tends to penalize the ISCCS configuration by requiring the system to operate at $50 \%$ annual capacity factor and then penalizing the solar for the inefficient use of natural gas. A comparison at a $25 \%$ annual capacity factor would show a much larger cost reduction for the ISCCS system over the Rankine cycle plant.

Table 3 provides a sensitivity analysis that compares current and future solar plants with the coal baseline system cost. From the table it is clear that power from parabolic trough plants is currently much more expensive than power from a conventional coal power plant. The future trough costs get much closer, but are still higher than the coal baseline. However using a \$25/tonne carbon credit, parabolic trough technology drops into the competitive range with coal power. The discount rate assumption has a significant impact on the analysis results.

\section{STPP COMMERCIALIZATION GAP}

In the long-term it is reasonable to expect the cost of parabolic trough technology to continue to decrease and approach the cost of conventional power. Since the current cost of trough power is greater than the cost of competing fossil technologies, someone must pay the non-economic incremental cost burden. In general, this is the role of the GEF. However, the GEF has multiple technologies it is helping to develop and must make sure it gets a good return for its investment. Primary question are: how much subsidy will be required to satisfy the noneconomic gap for this technology, and will entities other than the GEF help to shoulder this burden? For the World Bank study, an experience curve analysis is used to answer this question. 
Table 3 Sensitivity Analysis for Parabolic Trough Solar Power Plants [Enermodal, 1999]

\begin{tabular}{|c|c|c|c|c|}
\hline$\$ / k W h$ & $\begin{array}{c}\text { Coal-fired } \\
\text { Rankine } \\
\text { Plant }^{2}\end{array}$ & $\begin{array}{c}\text { Current } \\
\text { 30-MW } \\
\text { Rankine } \\
\text { Trough }\end{array}$ & $\begin{array}{c}\text { Current } \\
\text { 200-MW } \\
\text { Rankine } \\
\text { Trough }\end{array}$ & $\begin{array}{c}\text { Future } \\
200-M W \\
\text { Rankine } \\
\text { Trough }\end{array}$ \\
\hline Base case $^{1}$ & $0.043-0.069$ & 0.166 & 0.101 & 0.060 \\
\hline - $8 \%$ discount & $0.040-0.066$ & 0.146 & 0.89 & 0.053 \\
\hline$-12 \%$ discount & $0.046-0.072$ & 0.186 & 0.114 & 0.069 \\
\hline - $\$ 10 /$ tonne carbon credit & $0.043-0.069$ & 0.159 & 0.94 & 0.053 \\
\hline - $\$ 25 /$ tonne carbon credit & $0.043-0.069$ & 0.149 & 0.83 & 0.042 \\
\hline - $\$ 40 /$ tonne carbon credit & $0.043-0.069$ & 0.139 & 0.72 & 0.031 \\
\hline - $25 \%$ fuel cost increase & $0.046-0.072$ & 0.165 & 0.101 & 0.060 \\
\hline - $25 \%$ fuel cost decrease & $0.040-0.066$ & 0.166 & 0.101 & 0.060 \\
\hline-20 year plant life & $0.044-0.070$ & 0.174 & 0.107 & 0.064 \\
\hline-30 year plant life & $0.042-0.068$ & 0.161 & 0.098 & 0.059 \\
\hline
\end{tabular}

Experience Curve Analysis: The experience curve describes how unit cost decreases with increases in cumulative production [Neij, 1997]. A unique characteristic of the experience curve is that the cost declines by a constant percentage with each doubling of the total number of units produced. The experience curve phenomenon was first observed with aircraft production, but has since been found to hold true for many products including automobiles, calculators, computer chips, power plants, and renewable power technologies. For power technologies the experience curve can be used to track the capital cost or the LEC. The experience curve for LEC takes the algebraic form:

$$
L E C_{c u m}=C_{0} M W_{c u m}^{-b}
$$

Where:

$\mathrm{C}_{0}$ is the cost of the first MW produced

$\mathrm{MW}_{\text {cum }}$ is the cumulative MW produced to date

$\mathrm{b}$ is the experience index, and

$$
\text { LEC }_{\text {cum }} \text { is the LEC for last MW produced }
$$

The progress ratio $(P R)$ is the progress in cost reduction for every doubling of cumulative production. A PR of 0.80 means that the cost will be reduced by $20 \%$ by doubling cumulative production. The progress ratio is defined as:

$$
P R=2^{b}
$$

Progress ratios typically range from 0.60 to over 1.0 . Continuous processes usually have the lowest PRs. The following list provides shows estimated PRs for a number of technologies [Neij, 1997].

$\begin{array}{ll}\text { Automobiles } & 0.8 \\ \text { gas turbines } & 0.9 \\ \text { wind turbines } & 0.96 \\ \text { PV Modules } & 0.78-0.82\end{array}$

The LEC experience curve for the existing SEGS plants is shown in Figure 2. The experience curve appears as a straight line on a log/log plot of LEC verses cumulative megawatts installed. The progress ratio in this example is 0.85 .

In the case of power technologies, using experience curve analysis for LEC is attractive because it integrates the capital cost, O\&M costs, and plant performance into a single statistic. This is advantageous since these three parameters are not independent. Reducing capital cost, for example, can have a negative impact on O\&M costs and performance.

There are a number of reasons why the experience curve in Figure 2 could be misleading. First of all, the data are charted for the actual financed price, design plant performance, and an estimate of the necessary O\&M costs. The financed price of the SEGS plants is tied more to what the market would bear and less to the actual cost of the technology. In addition, the financed price included all the project development and financing costs, all of the Luz R\&D and corporate overhead, and warranty letters of credit. Adjusting for actual plant costs, the experience curve would likely be lower than it is shown in Figure 2. If these additional costs were a relatively constant percentage for all the projects, then 


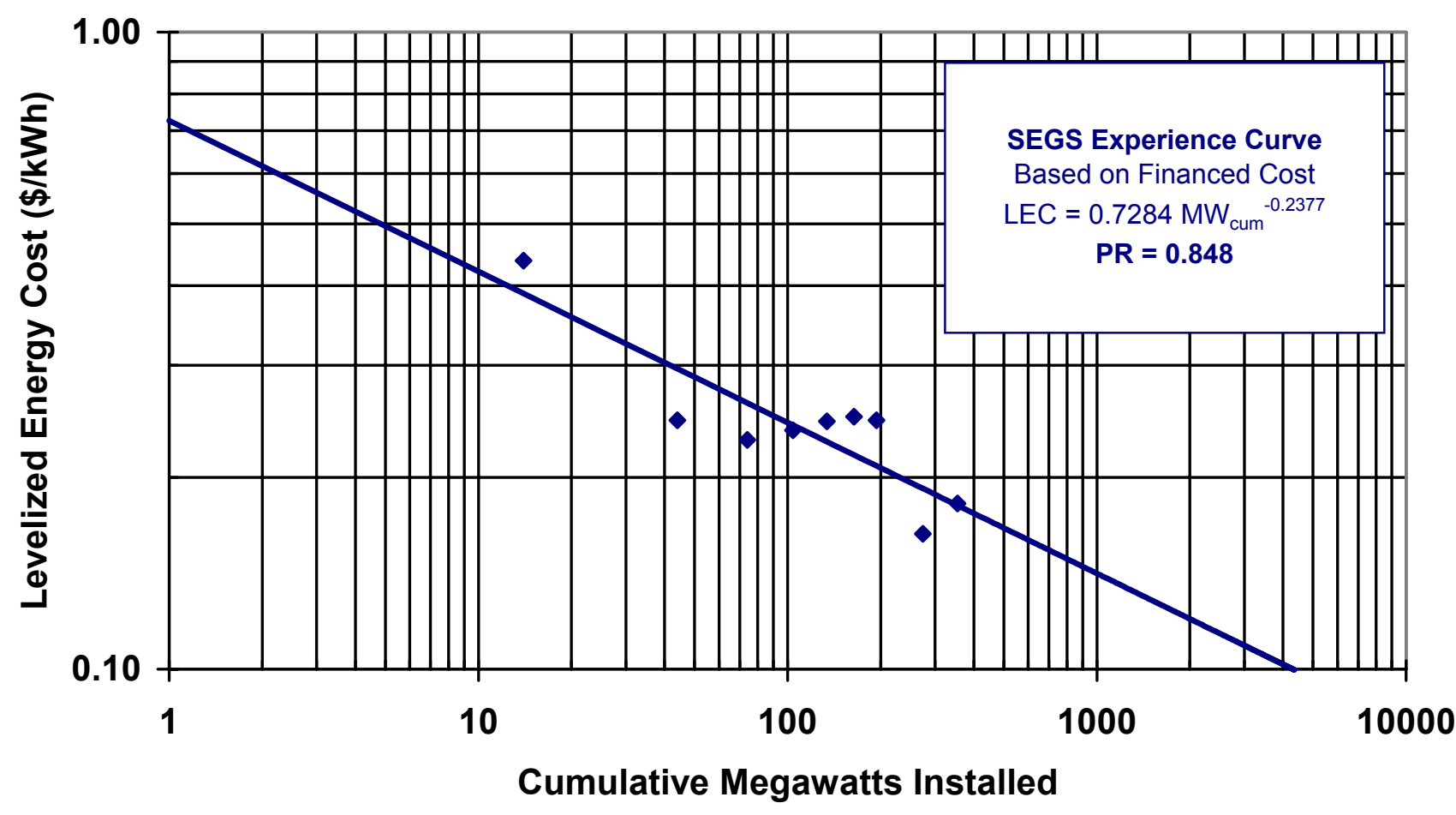

Figure 2 SEGS Plant LEC Experience Curve as a Function of Cumulative Megawatts Installed

the line would have the same slope. As mentioned previously, the plants have operated below design performance levels. However, since actual performance is tied to the O\&M expenditures it is not always clear whether current performance is related to the level of O\&M or the technology's actual capabilities. In general, the latter plants generally outperformed their predecessors. Using actual performance the learning curve slope is steeper with a progress ratio of $83 \%$.

The experience curve is useful for projecting the future cost of parabolic trough power plant technologies. If we assume that the $85 \%$ progress ratio is correct, we can use that to forecast future cost reductions. The main issue we face is deciding on a starting point for a next plant. Given the 10-year break in the development of trough power plants and given the technology advances in that period, it is reasonable to assume that there has been a break in the experience curve. The approach taken in the World Bank study uses the near-term 200MW plant as the starting point for the experience curve. Figure 3 highlights the future parabolic trough experience curve cost forecast using a progress ratio of $85 \%$. The cost for power from a coal-fired Rankine power plant is also shown. The shaded area between the two curves represents the non-economic or incremental cost subsidy required to buy-down trough technology to be competitive with conventional coal-fired power. Note the second coal technology cost line with a $\$ 25 /$ tonne of $\mathrm{CO} 2$ tax. This line is higher and thus the non-economic cost region between the two curves is significantly smaller, resulting in a much lower total subsidy required.

\section{STPP FUTURE DEVELOPMENT}

The Enermodal study developed a three-phase development plan for continued commercialization of STPPs. The three phases are market awareness, market expansion, and market acceptance. The plan assumes that the technology cost reduction continues along the learning curve. GEF grant support will be essential for the early phases to buy-down the incremental cost of the initial projects. In the longer-term, GEF support will likely be phased out as the technology cost begins to approach the cost of competing conventional technologies, especially in markets with higher fuel costs. The implementation of $\mathrm{CO} 2$ taxes will likely speed the development process and reduce the non-economic subsidies required to achieve economic parity.

\section{CONCLUSIONS}

The World Bank-sponsored "Cost Reduction Study for Solar Thermal Power Plants," demonstrated that parabolic troughs power plants are an attractive low greenhouse-gas-emission backstop technology.

Based on the extensive experience of the SEGS plants, parabolic trough technology is commercially proven technology and has demonstrated a significant cost reduction along its experience curve. 


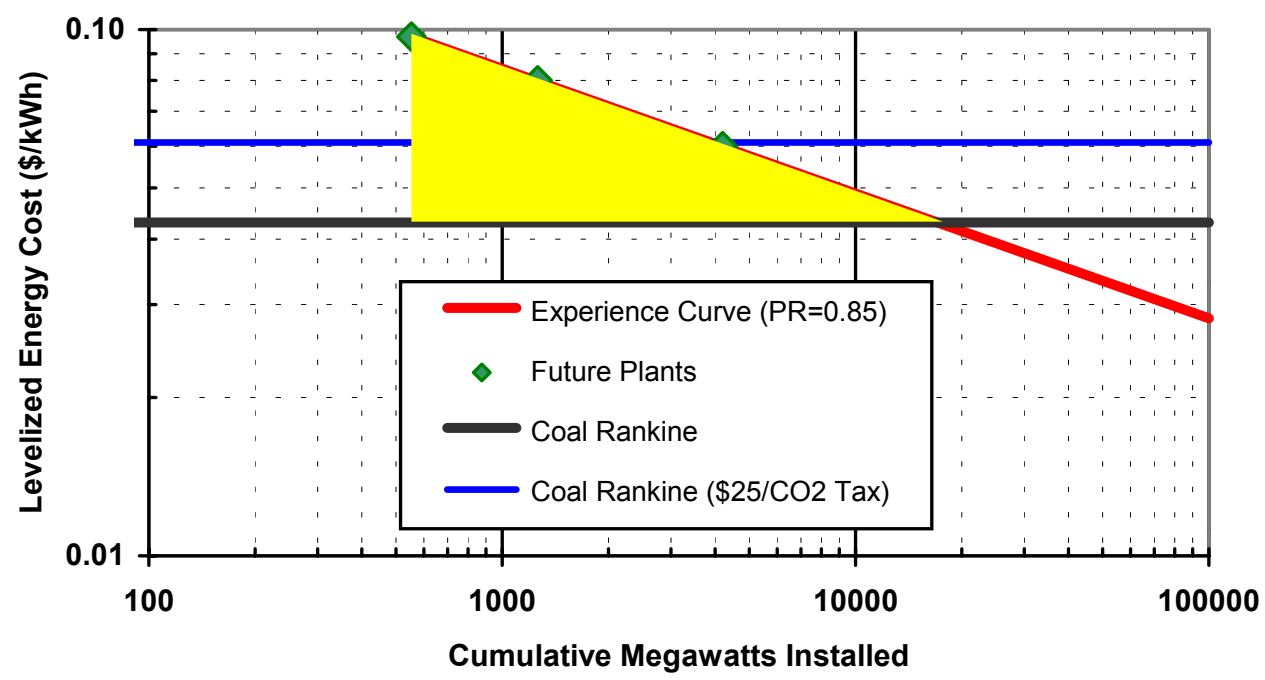

Figure 3 Trough Cost Forecast using Experience Curve

Based on lessons learned from the existing plants and experience curve analysis, expectations are that significant cost reduction is still possible. Future costs could approach the cost of conventional fossil power. Implementation of $\mathrm{CO} 2$ taxes would likely significantly accelerate the diffusion of parabolic trough technologies into the marketplace. The DOE-sponsored parabolic trough technology roadmap provides a pathway for helping to prioritize future RD\&D and deployment activities.

\section{REFERENCES}

Cable, R., Cohen, G., Kearney, D., and Price, H., 1998, "SEGS Plant Performance 1989-1997," ASME International Solar Energy Conference, Albuquerque, NM, June 1997.

EIA, 1999, "International Energy Outlook 1999 - Table A10: World Carbon Emissions by Region," DOE/EIA0484(99). www.eia.doe.gov/oiaf/ieo99/tabla9-11.html

EIA, 1998, "Annual Energy Outlook 1999," DOE/EIA0383(99).

http://www.eia.doe.gov/oiaf/aeo99/homepage.html

Entermodal, 1999, "Cost Reduction Study For Solar Thermal Power Plants," Final Report, Prepared for the World Bank, Washington DC, May 5, 1999.

Gas Turbine World, 1998-99, "1998-99 Handbook For Project Planning, Design, and Construction," Vol. 19, ISSN 0747-7988, Pequot Publishing, Fairfield, CT.

GEF, 1999a, "Welcome to the Global Environment Facility," web page. http://www.gefweb.org/

GEF, 1996, "Operational Strategy of the Global Environment," Washington, DC, 1996.
GEF, 1996, "Incremental Costs," GEF/C.7/Inf. 5, February 29, 1996.

GEF, 1999, "GEF Pipelines of Implementing Agencies,"GEF/C.13/Inf.7, April 1999.

Kolb, 1997, "Economic Evaluation of Solar-Only and Hybrid Power Towers Using Molten-Salt Technology," Elsevier Science Ltd., Great Britain.

Lotker, M., 1991, "Barriers to Commercialization of LargeScale Solar Electricity: Lessons Learned from the Luz Experience," SAND91-7014, Sandia National Laboratories, Albuquerque, NM.

Neij, L., 1997, "Use of experience curves to analyse the prospects for diffusion and adoption of renewable energy technology," Energy Policy, Vol. 23. No. 13, pp. 10991107, Elsevier Science Ltd, Great Britain, 1997.

Pilkington, 1996, "Status Report on Solar Trough Power Plants," Prepared for the German Federal Ministry for Education , Science, Research and Technology. Prepared by Pilkington Solar International, ISBN 39804901-0-6, Köln, Germany.

Price, H., Kearney, K, 1999, "Parabolic Trough Technology Roadmap: A pathway for sustained commercial development and deployment of parabolic trough technology," NREL/TP-550-24748. 
Public reporting burden for this collection of information is estimated to average 1 hour per response, including the time for reviewing instructions, searching existing data sources, gathering and maintaining the data needed, and completing and reviewing the collection of information. Send comments regarding this burden estimate or any other aspect of this

collection of information, including suggestions for reducing this burden, to Washington Headquarters Services, Directorate for Information Operations and Reports, 1215 Jefferson Davis Highway, Suite 1204, Arlington, VA 22202-4302, and to the Office of Management and Budget, Paperwork Reduction Project (0704-0188), Washington, DC 20503.

\begin{tabular}{|l|l|l|l}
\hline 1. AGENCY USE ONLY (Leave blank) & $\begin{array}{l}\text { 2. REPORT DATE } \\
\text { May } 1999\end{array}$ & $\begin{array}{l}\text { 3. REPORT TYPE AND DATES COVERED } \\
\text { Conference Paper }\end{array}$ \\
\hline
\end{tabular}

\section{TITLE AND SUBTITLE}

The Potential for Low-Cost Concentrating Solar Power Systems

5. FUNDING NUMBERS

Task \#: SE913002

\section{AUTHOR(S)}

Henry W. Price and Stephen Carpenter

7. PERFORMING ORGANIZATION NAME(S) AND ADDRESS(ES)

National Renewable Energy Laboratory Enermodal Engineering

1617 Cole Boulevard 1554 Emerson Street

Golden, CO 80401-3393 Denver, CO (USA) 80218

\section{SPONSORING/MONITORING AGENCY NAME(S) AND ADDRESS(ES)}

National Renewable Energy Laboratory

1617 Cole Boulevard

Golden, CO 80401-3393

\section{SUPPLEMENTARY NOTES}

\section{2a. DISTRIBUTION/AVAILABILITY STATEMENT}

National Technical Information Service

U.S. Department of Commerce

5285 Port Royal Road

Springfield, VA 22161

13. ABSTRACT (Maximum 200 words) Concern over the possibility of global climate change as a result of anthropogenic greenhouse gas buildup in the atmosphere is resulting in increased interest in renewable energy technologies. The World Bank recently sponsored a study to determine whether solar thermal power plants can achieve cost parity with conventional power plants. The paper reviews the conclusions of that study.

14. SUBJECT TERMS troughs, parabolic troughs, solar trough, csp, concentrating solar power, sunlab, solar power, solar thermal electric, cost of electricity

17. SECURITY CLASSIFICATION OF REPORT
18. SECURITY CLASSIFICATION OF THIS PAGE
19. SECURITY

CLASSIFICATION

OF ABSTRACT
15. NUMBER OF PAGES

8

16. PRICE CODE 